\title{
Respons Pertumbuhan Bibit Kelapa Sawit (Elaeis guineensis Jacq.) Terhadap Decanter Solid di Pembibitan Utama
}

\author{
${ }^{1}$ Sarman, ${ }^{1}$ Elly Indraswari, dan ${ }^{* 1}$ Ahmad Husni \\ ${ }^{* 1}$ Program Studi Agroekoteknologi, Fakultas Pertanian, Universitas Jambi \\ Jalan Raya Jambi - Ma. Bulian 15 Mendalo Indah 36136 (082289205428) \\ ${ }^{* 1}$ e-mail korespondensi : husniahmad178@gmail.com
}

\begin{abstract}
Oil palm is one of the most important plantation crops in the plantation sector in Indonesia. Oil palm (Elaeis guineensis Jacq) is a vegetable oil-producing plant in the form of Crude Palm Oil (CPO). CPO productivity is very much determined by quality and productive seeds. This study aims to determine the response of oil palm seedling growth to the provision of solid food containers and phosphate fertilizers at various doses in the main nursery. This research was conducted at the Teaching and Research Farm, Faculty of Agriculture, Jambi University, Mendalo Indah, Jambi Luar Kota District, Muaro Jambi Regency. This research was conducted for 3 months from September to December 2019. Design of the experiment used a randomized block design (RBD) with one factor, the application of various solid decanter compositions consisting of 6 treatments levels : $p 0=$ fertilizer $N P K M g 44 \mathrm{~g} \mathrm{polybag}^{-1} ; \mathrm{pl}=$ decanter solid $140 \mathrm{~g}_{\text {polybag }} \mathrm{p}^{-1}$; $2=$ decanter solid $240 \mathrm{~g}$ polybag ${ }^{-1}$; p3 = decanter solid $340 \mathrm{~g}_{\text {polybag }}^{-1} ; \mathrm{p} 4=$ decanter solid $440 \mathrm{~g}_{\text {polybag }}^{-1}$; and $\mathrm{p} 5=$ decanter solid $540 \mathrm{~g}$ polybag-1. Variables observed were plant height, number of leaves, stem diameter, total leaf area, root dry weight, shoot dry weight, and shoot- root ratio. The results showed that giving solid decanter at various doses was able to increase growth in all observed variables and was able to sow seedling growth at recommended fertilization doses. The application of solid decanter $140 \mathrm{~g}$ polybag-1 is the best dose to increase the seed height variable and able to exceed the seed height at the recommended dose of fertilizing oil palm seedlings in the main nursery.
\end{abstract}

Keywords : decanter solid, oil palm seedling, fospor

\begin{abstract}
Abstrak. Kelapa sawit merupakan salah satu tanaman perkebunan yang menduduki posisi penting dalam sektor perkebunan di Indonesia. Kelapa sawit (Elaeis guineensis Jacq.) merupakan tanaman penghasil minyak nabati berupa Crude Palm Oil (CPO). Produktivitas CPO sangat ditentukan oleh bibit yang berkualitas dan produktif. Penelitian ini bertujuan mempelajari respons pertumbuhan bibit kelapa sawit terhadap pemberian decanter solid dan pupuk fosfat pada berbagai dosis di pembibitan utama. Penelitian ini dilaksanakan di Teaching and Research Farm Fakultas Pertanian Universitas Jambi, Mendalo Indah, Kecamatan Jambi Luar Kota, Kabupaten Muaro Jambi. Penelitian ini dilaksanakan pada bulan September sampai Desember 2019. Penelitian ini menggunakan rancangan acak kelompok (RAK) dengan satu faktor yaitu aplikasi berbagai komposisi decanter solid yang

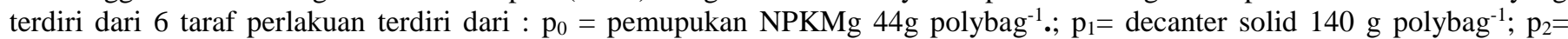
decanter solid $240 \mathrm{~g}$ polybag $^{-1}, \mathrm{p}_{3}=$ decanter solid $340 \mathrm{~g}_{\text {polybag }}{ }^{-1} ; \mathrm{p}_{4}=$ decanter solid $440 \mathrm{~g} \mathrm{polybag}^{-1} ; \mathrm{p}_{5}=$ decanter solid $540 \mathrm{~g}$ polybag $^{-1}$. Peubah yang diamati adalah pertambahan tinggi tanaman, pertambahan jumlah daun, pertambahan diameter batang, total luas daun, bobot kering akar, bobot kering tajuk, dan rasio tajuk akar. Hasil penelitian menunjukan pemberian Decanter Solid pada berbagai dosis dengan penambah 13 g TSP polybag ${ }^{-1}$, mampu meningkatkan pertambahan pertumbuhan bibit kelapa sawit pada semua variabel pengamatan dan mampu menyamai pertumbuhan bibit pada dosis pupuk rekomendasi. Pemberian decanter solid $140 \mathrm{~g}_{\text {polybag }}{ }^{-1}$ merupakan dosis terbaik meningkatkan pertambahan tinggi bibit dan mampu melebihi pertambahan tinggi bibit pada dosis rekomendasi pemupukan bibit kelapa sawit di pembibitan utama.
\end{abstract}

Kata Kunci : decanter solid, kelapa sawit, fosfor

\section{PENDAHULUAN}

Kelapa sawit merupakan salah satu tanaman perkebunan yang menduduki posisi penting dalam sektor pertanian umumnya, dan sektor perkebunan khususnya.Kelapa sawit (Elaeis guineensis Jacq.) merupakan tanaman penghasil minyak nabati yang berupa Crude Palm Oil (CPO).

Kelapa sawit (Elaeis guineensis Jacq) merupakan komoditi sub sektor perkebunan yang penting bagi perekonomian di Indonesia, dikarenakan kelapa sawit sebagai penghasil minyak nabati, maupun bahan bakar biodiesel yang banyak memberikan keuntungan besar bagi masyarakat dan pemerintah.Produktivitas kelapa sawit di Provinsi Jambi tergolong masih rendah yakni sebesar 3,2 ton/ha dibandingkan produktivitas nasional sebesar 3,8 ton/ha, hal ini disebabkan karena sebagian besar perkebunan kelapa sawit di Provinsi Jambi didominasi oleh perkebunan kelapa sawit rakyat yang pada umumnya mengelola kebun secara kurang baik, misalnya dalam penyediaan bibit. Untuk meningkatkan produktivitas kelapa sawit, salah satunya adalah penggunaan bibit yang berkualitas dan produktif yang dihasilkan dari manajemen pembibitan yang baik. Upaya peningkatan kualitas bibit siap tanaman di lapang dilakukan dengan berbagai cara, diantaranya memberikan perlakuan pada media bibit dengan memanfaatkan decanter solid yang dikombinasikan dengan pupuk an-organik. 
Bibit yang unggul merupakan modal dasar untuk mencapai produktivitas yang tinggi. Standar bibit yang baik dapat dilihat dari diameter batang (tegak), tinggi bibit (jagur), jumlah daun (cukup), dan tidak terserang hama penyakit (Hertos, 2013). Untuk mendapatkan bibit yang baik diperlukan pemupukan yang tepat agar kebutuhannya akan unsur hara dapat terpenuhi, oleh karena itu perlu dilakukan pemberian pupuk yang optimal. Salah satu pupuk organik dapat digunakan yaitu pemamfaatan limbah pabrik kelapa sawit, salah satu sumber bahan organik yang tersedia dalam jumlah besar adalah decanter solid. Limbah decanter solid dari pabrik pengolahan kelapa sawit yang telah menjadi kompos memiliki potensi yang cukup besar untuk dimanfaatkan sebagai bahan campuran dalam media tanam pada pembibitan kelapa sawit, karena setiap ton pengolahan TBS dapat menghasilkan 4\% decanter solid. Menurut Pahan (2010) decanter solid berasal dari mesocarp atau serabut berondolan sawit yang telah mengalami pengolahan di PKS. Decanter solid merupakan produk akhir berupa padatan dari proses pengolahan TBS di PKS yang memakai sistem decanter. Decanter digunakan untuk memisahkan fase cair (minyak dan air) dari fase padat sampai partikel-partikel terakhir. Decanter dapat mengeluarkan 90\% semua padatan dari lumpur sawit dan $20 \%$ padatan terlarut dari minyak sawit. Unsur hara yang terkandung dalam decanter solid berdasarkan hasil analisis sampel di Laboratorium Pusat Penelitian Kelapa sawit di Sumatera Utara yaitu Nitrogen (N) 0,472\%, Phospor (P) 0,046\%, K2O 0,304\%, Magnesium (Mg) 0,070\% (Pahan, 2010).

Berdasarkan hasil penelitian Novsel et.al (2016), menunjukan bahwa pemberian decanter solid dapat mensubsitusi pupuk NPKMg pada bibit kelapa sawit di pembibitan utama dan berpengaruh baik terhadap pertambahan tinggi bibit, diameter bibit, jumlah daun, total luas daun, bobot kering tajuk, bobot kering akar dan rasio tajuk akar. Pemberian 25\% decanter solid (450 g ) + $75 \%$ NPKMg memperlihatkan pertumbuhan bibit kelapa sawit terbaik.

Penelitian ini bertujuan untuk mempelajari respons bibit kelapa sawit (Elaeis guineensis Jacq) terhadap decanter solid pada berbagai dosis dan ditambah dengan pupuk fosfat di pembibitan utama serta untuk mendapatkan dosis decanter solid yang terbaik terhadap pertumbuhan bibit kelapa sawit di pembibitan utama.

\section{METODE PENELITIAN}

Penelitian ini dilaksanakan di Teaching and Research farm Fakultas Pertanian Universitas Jambi, Mendalo Indah, Kecamatan Jambi Luar Kota, Kabupaten Muaro Jambi. Penelitian ini dilaksanakan 3 bulan mulai bulan September sampai Desember 2019.

Bahan yang digunakan adalah bibit kelapa sawit D X P Tenera umur \pm 4 bulan (Karakteristik Kelapa Sawit D X P Tenera), decanter solid (Hasil analisis decanter solid yang digunakan dalam peneltian ini yang dilaksanakan di Laboratorium BPTP Jambi adalah sebagai berikut ; pH 6,62, C-org 18,41, N-total 0,93, C/N 19,79, P-total 0,39 dan K-total 0,16.), tanah top soil ( Ultisol), pupuk TSP, pupuk NPKMg, Dithane M-45 dan Decis. Sedangkan alat yang digunakan adalah cangkul, parang, polybag ukuran $40 \mathrm{~cm}$ x $50 \mathrm{~cm}$, gembor, meteran, jangka sorong, tali rafia, oven, timbangan analitik, ayakan, parang, gunting, sekop, kayu, alat tulis, hand sprayers dan kamera.

Penelitian ini menggunakan rancangan acak kelompok (RAK) dimana yang dikelompokan adalah tinggi tanaman dengan 6 perlakuan sebagai berikut :p0 : pemupukan NPKMg 44g polybag-1, p1 :decanter solid $140 \mathrm{~g}$ polybag $^{-1}, \mathrm{p} 2$ :decanter solid $240 \mathrm{~g}_{\text {polybag }}{ }^{-1}, \mathrm{p} 3:$ decanter solid $340 \mathrm{~g}_{\text {polybag }}{ }^{-1}, \mathrm{p} 4:$ decanter solid $440 \mathrm{~g}$ polybag${ }^{1}$, dan $\mathrm{p} 5$ : decanter solid 540 polybag $^{-1}$.

Setiap perlakuan diulang sebanyak 4 kali sehingga terdapat 24 satuan percobaan, jarak antar perlakuan 60 $\mathrm{cm}$, sedangkan jarak antar ulangan $60 \mathrm{~cm}$, dengan jarak antara polybag $30 \mathrm{~cm} \times 30 \mathrm{~cm}$. Setiap satuan percobaan terdiri dari 3 tanaman dan diambil 2 tanaman sebagai sampel, dengan demikian seluruh tanaman adalah 72 tanaman. Untuk mengetahui pengaruh variabel yang diamati, maka data yang diperoleh dalam penelitian ini dianalisis secara statistik dengan menggunakan analisis ragam yang kemudian dilanjutkan dengan uji Duncan New Multiple Range Test (DNMRT) dengan taraf $a=5 \%$.

Pelaksanaan penelitian dilakukan dengan beberapa tahapan; 1) persiapan bibit. Bibit yang digunakan adalah bibit kelapa sawit yang berumur \pm 4 bulan, yang belum diberi pupuk lanjutan. Semua bibit diseleksi terlebih dahulu dan dilakukan pengukuran awal terhadap variabel tinggi bibit, jumlah daun dan diamater batang dengan hasil berturut-turut sebagai berikut; 29,5 - $35 \mathrm{~cm}, 4-5$ helai serta diamter batang $10-11 \mathrm{~mm}$. 2) persiapanan media. Decanter solid yang digunakan adalah decanter solid yang sudah dikeringkan \pm 1 minggu, kemudian diayak dan dcampur dengan tanah pengisi polybag yang diambil dari lapisan atas jenis tanah Ultisol sebanyak $\pm 15 \mathrm{~kg}$, Setelah dicampur merata, kemudian diinkubasi selama 1 minggu. 3) penanaman bibit dilakukan setelah media diinkubasi. Penanaman dilakukan dengan cara memindahkan bibit kelapa sawit dari polybag kecil ke polybag besar berukuran $40 \times 50 \mathrm{~cm}$. 4) pemberian pupuk TSP sebanyak 13 g pada perlakuan p1, p2, p3, p4 dan p5 dilakukan dengan cara ditugal melingkar di sekitar tanaman dengan jarak $\pm 4 \mathrm{~cm}$, sedangkan untuk perlakuan p0 (pemupukan $\mathrm{NPKMg}$ diberikan sebanyak $44 \mathrm{~g}$ secara bertahap 2 minggu sekali sampai akhir penelitian. 
Variabel pengamatan terdiri dari; pertambahan tinggi bibit $(\mathrm{cm})$, pertambahan jumlah daun (helai), pertambahan diameter batang $(\mathrm{mm})$, luas daun total $\left(\mathrm{cm}^{2}\right)$, bobot kering tajuk $(\mathrm{g})$, bobot kering akar $(\mathrm{g})$, rasio tajuk akar.

1. Pengukuran pertambahan tinggi bibit dilakukan diawal pada saat bibit baru dipindahkan ke dalam polybag dan selanjutnya dilakukan 2 minggu setelah tanam. Pengukuran dilakukan setiap 2 minggu dan untuk mendapatkan data pertambahan tinggi bibit, data pengukuran 2 minggu sekali dikurangi dengan data pengukuran awal tinggi tanaman sampai akhir penelitian (umur bibit 28 minggu).

2. Pengukuran pertambahan jumlah daun dilakukan pada awal penelitian sampai akhir (umur bibit 28 minggu), dengan interval waktu 2 minggu sekali dengan cara pengukuran setiap 2 minggu sekali dikurangi dengan data pengukuran awal jumlah daun. Daun yang dihitung adalah helai daun telah terbuka sempurna.

3. Pertambahan diameter batang diukur pada awal penelitian sampai akhir penelitian (umur bibit 28 minggu), dengan interval waktu 2 minggu sekali.Pengukuran dilakukan dengan menggunakan jangka sorong dan dilakukan $2 \mathrm{~cm}$ diatas pangkal batang (pada bonggol). Data pertambahan diameter batang diperoleh dengan cara pengukuran setiap 2 minggu dikurangi dengan data pengukuran awal diamater batang.

4. Total luas daun diukur sebanyak 1 kali dan dilakukan pada akhir penelitian (umur bibit 28 minggu). Pengukuran luas daun dilakukan secara manual dengan mengukur panjang daun dari pangkal daun hingga ujung daun, kemudian mengukur lebar daun dengan cara mengukur lebar pada tengah daun yang telah membuka sempurna, kemudian luas ditotalkan dengan menggunakan rumus $\mathrm{L} \times \mathrm{W}$ x $\mathrm{K}$ dimana $\mathrm{L}=$ Panjang daun, $\mathrm{W}=$ Lebar daun, $\mathrm{K}$ $=$ Konstanta dimana $0,57=$ nilai konstanta daun yang belum membelah (lanceolate), dan $0,5=$ nilai konstanta daun yang telah membelah (bifurcate).

5. Bobot kering tajuk diukur pada akhir penelitian (umur bibit 28 minggu). Tanaman sampel dibongkar kemudian dibersihkan dengan air, kemudian dipisahkan antara akar dengan bagian tajuk tanaman. Bagian tajuk tanaman sampel kemudian dikeringoven pada suhu $80^{\circ} \mathrm{C}$ selama $2 \times 24$ jam, lalu ditimbang. Pengamatan dan penimbangan dilakukan 3 kali sampai didapat bobot kering konstan.

6. Bobot kering akar diukur pada akhir penelitian (umur bibit 28 minggu), akar tanaman sampel dibongkar dan dibersihkan dari tanah dengan menggunakan air. Kemudian akar dipotong dari pangkal akar dan dikering oven dengan suhu $80^{\circ} \mathrm{C}$ selama 2 × 24 jam. Selanjutnya akar dari oven dan ditimbang sebanyak 3 kali sampai didapat data bobot kering akar konstan.

7. Rasio tajuk akar diukur diperoleh dari data bobot kering tajuk dan bobot kering akar dengan menggunakan rumus Rasio Tajuk Akar $=\frac{B K T}{B K A}$ dimana $:$ BKT $=$ Bobot Kering Tajuk dan BKA $=$ Bobot Kering Akar.

Data penunjang yang digunakan dalam penelitian ini adalah, analisis tanah awal yang meliputi $\mathrm{N}, \mathrm{P}, \mathrm{K}, \mathrm{pH}$, C-Organik, analisis decanter solid yang meliputi kandungan N, P, K. C-Organik, pH, data suhu, kelembapan udara dan curah hujan selama penelitian. Data diperoleh dari stasiun Klimatologi Muaro Jambi. Untuk mengetahui pengaruh perlakuan terhadap variabel yang diamati, maka data yang diperoleh dalam penelitian ini dianalisis secara statistik dengan menggunakan analisis ragam dan dilanjutkan dengan uji Duncan New Multiple Range Test (DNMRT) dengan taraf $\mathrm{a}=5 \%$.

\section{Pertambahan Tinggi Bibit}

\section{HASIL DAN PEMBAHASAN}

Berdasarkan hasil analisis ragam menunjukkan bahwa perlakuan pemberian decanter solid dan pupuk fosfat berpengaruh nyata terhadap pertambahan tinggi bibit kelapa. Hasil uji Duncan pada taraf $a=5 \%$ terhadap pertambahan tinggi bibit dapat dilihat pada Tabel 1.

Tabel 1. Rata-rata pertambahan tinggi bibit kelapa sawit umur 12 MST

\begin{tabular}{lc}
\hline \multicolumn{1}{c}{ Perlakuan } & Tinggi Bibit (cm) \\
\hline Pemupukan NPKMg 44 g polybag-1 & $14,34 \mathrm{~b}$ \\
Decanter solid 140 g polybag & $25,19 \mathrm{a}$ \\
Decanter solid 240 g polybag & \\
Decanter solid $340 \mathrm{~g} \mathrm{polybag}^{-1}$ & $19,81 \mathrm{a}$ \\
Decanter solid $440 \mathrm{~g} \mathrm{polybag}^{-1}$ & $20,83 \mathrm{a}$ \\
Decanter solid 540 g polybag & \\
\hline
\end{tabular}

Keterangan : Angka-angka yang diikuti oleh huruf yang sama berbeda tidak nyata menurut uji DNMRT pada taraf $\alpha$ $=5 \%$. 
Berdasarkan Tabel 1 menunjukkan bahwa pemberian perlakuan decanter solid $140 \mathrm{~g}$ dengan penambahan 13 g pupuk TSP polybag ${ }^{-1}$ menghasilkan pertambahan tinggi bibit tertinggi yaitu $25,19 \mathrm{~cm}$, berbeda nyata dengan

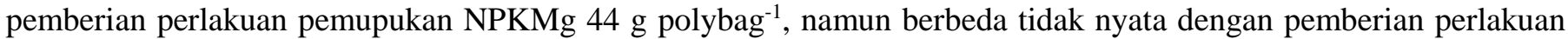
decanter solid pada dosis berturut ; $240 \mathrm{~g}, 340 \mathrm{~g}, 440 \mathrm{~g}^{-1 a n} 540 \mathrm{~g}_{\text {polybag }}{ }^{-1}$ dengan masing-masing perlakuan juga ditambah $13 \mathrm{~g}$ pupuk TSP. Pemberian pupuk NPKMg sebanyak $44 \mathrm{~g}$ polybag ${ }^{-1}$ menghasilkan pertambahan tinggi bibit yang terendah yaitu $14,34 \mathrm{~cm}$.

Grafik pertambahan tinggi bibit kelapa sawit umur 4 bulan di pembibitan utama setiap 2 minggu pengamatan disajikan pada Gambar 1. Pada grafik terlihat bahwa pertambahan tinggi bibit kelapa sawit di pembibitan utama pada 2 MST sampai 6 MST belum menunjukan kecenderungan peningkatan pertambahan tinggi bibit pada semua perlakuan. Namun pada minggu ke 6 sampai ke 12 MST pada grafik terlihat bahwa perlakuand Decanter solid dengan penambahan $13 \mathrm{~g}$ pupuk TSP menunjukkan peningkatkan pertambahan tinggi bibit sawit yang cukup pesat jika dibandingkan dengan kontrol (rekomendasi pemupukan NPKMg sebanyak $44 \mathrm{~g} \mathrm{polybag}^{-1}$ ).

\section{Pertambahan Jumlah Daun}

Berdasarkan hasil analisis ragam menunjukkan bahwa perlakuan pemberian decanter solid yang ditambah 13 g pupuk TSP tidak berpengaruh nyata terhadap pertambahan jumlah daun bibit kelapa sawit. Hasil pengamatan terhadap pertambahan jumlah daun tersaji pada Tabel 2.

Pada Tabel 2 menunjukan bahwa pemberian NPKMg $44 \mathrm{~g}^{\text {polybag }}{ }^{-1}$ dan decanter solid yang ditambah pupuk TSP memberikan perbedaan tidak nyata terhadap pertambahan jumlah daun kelapa sawit. Jika dilihat berdasarkan angka, perlakuan dengan pemberian decanter solid $140 \mathrm{~g} \mathrm{polybag}^{-1}$ menghasilkan pertambahan jumlah daun terbanyak yaitu 3,75 helai daun. Sedangkan pemberian perlakuan rekomendasi pemupukan NPKMg $44 \mathrm{~g}$ polybag $^{-1}$ dan pemberian decanter solid $440 \mathrm{~g}$ polybag $^{-1}$ menghasilkan pertambahan jumlah daun terendah yaitu 3,25 helai.

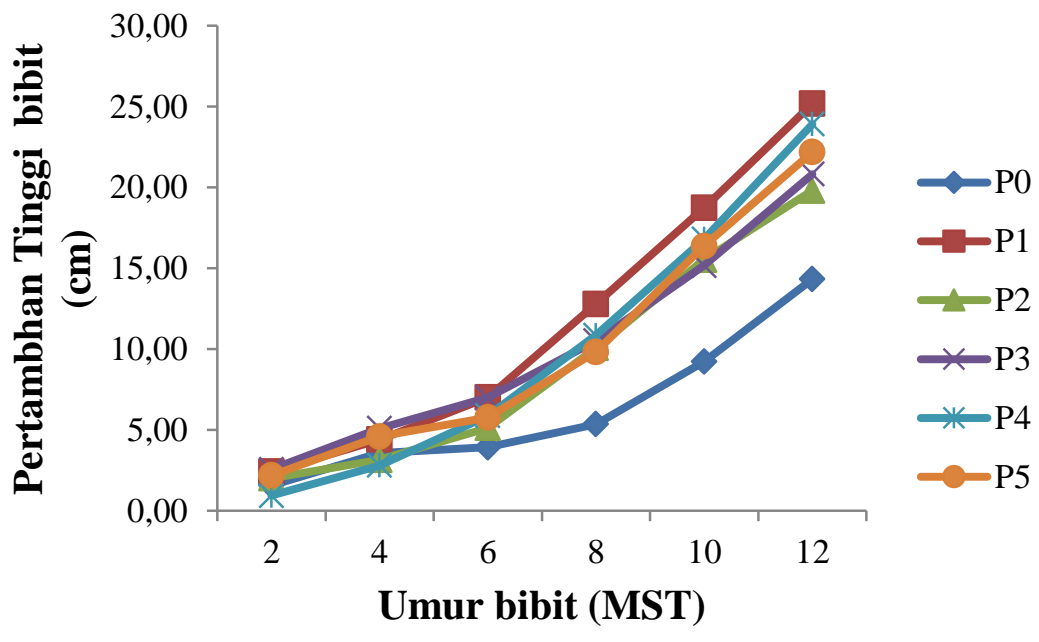

p0 (pemupukan NPKMg $44 \mathrm{~g}$ polybag $^{-1}$ )

p1 (decanter solid $140 \mathrm{~g} \mathrm{polybag}^{-1}$ )

p2 (decanter solid $240 \mathrm{~g}_{\text {polybag }^{-1}}$ )

p3 (decanter solid $340 \mathrm{~g}_{\text {polybag }^{-1}}$ )

p4 (decanter solid $440 \mathrm{~g}_{\text {polybag }^{-1}}$ )

p5 (decanter solid $540 \mathrm{~g} \mathrm{polybag}^{-1}$ )

Gambar 1. Grafik pertambahan tinggi bibit kelapa sawit umur 4 bulan di pembibitan utama 
Sarman Sarman, Elly Indraswari dan Ahmad Husni. Respons Pertumbuhan Bibit Kelapa Sawit (Elaeis guineensis Jacq.)

Tabel 2. Rata-rata pertambahan jumlah daun bibit kelapa sawit umur 12 MST

\begin{tabular}{lc}
\hline Perlakuan & Jumlah daun (Helai) \\
\hline Pemupukan NPKMg 44 g polybag-1 & $3,25 \mathrm{a}$ \\
Decanter solid 140 g polybag & $3,75 \mathrm{a}$ \\
Decanter solid 240 g polybag & \\
Decanter solid 340 g polybag & $3,38 \mathrm{a}$ \\
Decanter solid 440 g polybag-1 & $3,63 \mathrm{a}$ \\
Decanter solid 540 g polybag & $3,25 \mathrm{a}$ \\
\hline
\end{tabular}

Keterangan :Angka-angka yang diikuti oleh huruf yang sama berbeda tidak nyata menurut uji DNMRT pada taraf $\alpha=5 \%$.

\section{Pertambahan Diameter Batang}

Berdasarkan hasil analisis ragam menunjukkan bahwa perlakuan pemberian decanter solid yang ditambah 13 g pupuk TSP tidak berpengaruh nyata terhadap pertambahan diameter batang bibit kelapa sawit. Hasil uji Duncan pada taraf $a=5 \%$ terhadap pertambahan diameter batang bibit dapat dilihat pada Tabel 3 .

Pada Tabel 3 dapat dilihat bahwa pemberian perlakuan rekomendasi pemupukan dan pemberian decanter solid yang ditambah pupuk TSP memberikan perbedaan tidak nyata terhadap pertambahan diameter batang kelapa

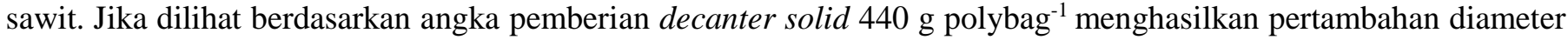
batang terbesar yaitu $15,30 \mathrm{~mm}$, sedangkan pemberian pemupukan NPKMg $44 \mathrm{~g}^{\text {polybag }}{ }^{-1}$ menghasilkan pertambahan diameter batang terkecil yaitu $12,63 \mathrm{~mm}$.

Tabel 3. Rata-rata pertambahan diameter batang bibit kelapa sawit umur 12 MST

\begin{tabular}{lc}
\hline Perlakuan & Diamaeter Batang (mm) \\
\hline Pemupukan NPKMg 44 g polybag $^{-1}$ & $12,63 \mathrm{a}$ \\
Decanter solid 140 g polybag-1 & $15,03 \mathrm{a}$ \\
Decanter solid 240 g polybag- & $14,41 \mathrm{a}$ \\
Decanter solid 340 g polybag & $14,79 \mathrm{a}$ \\
Decanter solid 440 g polybag & $15,30 \mathrm{a}$ \\
Decanter solid 540 g polybag & $14,61 \mathrm{a}$ \\
\hline
\end{tabular}

Keterangan : Angka-angka yang diikuti oleh huruf yang sama berbeda tidak nyata menurut uji DNMRT pada taraf $\alpha$ $=5 \%$.

Grafik pertambahan diameter batang bibit kelapa sawit umur 4 bulan di pembibitan utama setiap 2 minggu pengamatan tersaji pada Gambar 2. Pada grafik terlihat bahwa pertambahan diameter batang bibit kelapa sawit di pembibitan utama pada pengamatan setiap 2 minggu mulai dari minggu ke-2 sampai 12 MST terus menunjukkan pertambahan.

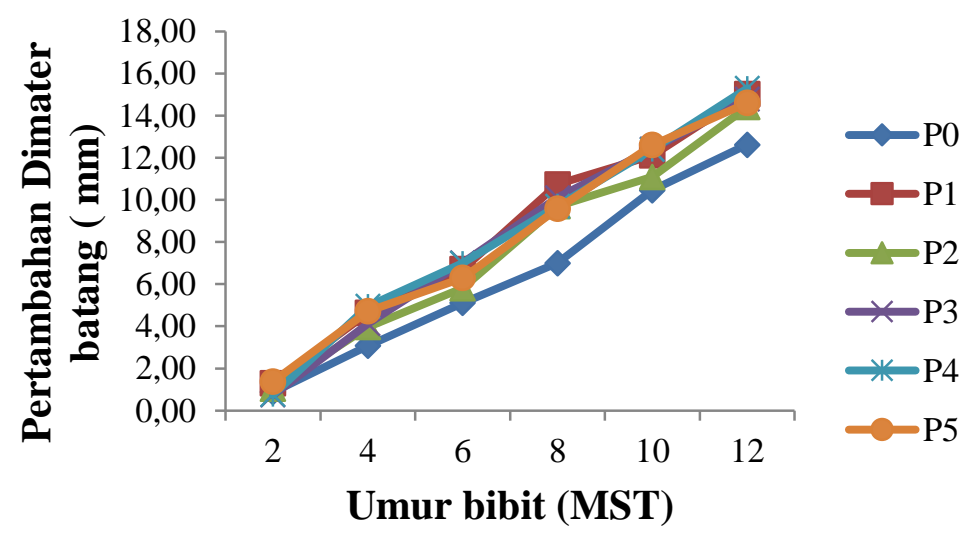

p0 (pemupukan NPKMg 44 g polybag $^{-1}$ )

p1 (decanter solid $140 \mathrm{~g}_{\text {polybag }}{ }^{-1}$ )

p2 (decanter solid $240 \mathrm{~g}_{\text {polybag }}^{-1}$ )

p3 (decanter solid $340 \mathrm{~g}_{\text {polybag }}^{-1}$ )

p4 (decanter solid $440 \mathrm{~g}_{\text {polybag }}^{-1}$ )

p5 (decanter solid 540 g polybag $^{-1}$ )

Gambar 2. Grafik pertambahan diamater batang bibit kelapa sawit umur 4 bulan di pembibitan utama 


\section{Luas Daun Total}

Berdasarkan hasil analisis ragam menunjukkan bahwa perlakuan pemberian decanter solid dengan penambahan $13 \mathrm{~g}$ pupuk TSP tidak berpengaruh nyata terhadap luas daun total bibit kelapa sawit. Hasil uji Duncan pada taraf $a=5 \%$ terhadap luas daun total bibit dapat dilihat pada Tabel 4.

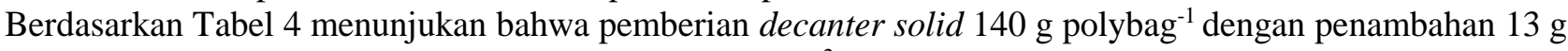
pupuk TSP menghasilkan luas daun terluas yaitu $1375,18 \mathrm{~cm}^{2}$. Perlakuan ini berbeda nyata dengan pemberian perlakuan rekomendasi pemupukan NPKMg $44 \mathrm{~g}_{\text {polybag }}^{-1}$, namun berbeda tidak nyata dengan pemberian pemberian decanter solid dengan dosis berturut-turut ; $240 \mathrm{~g}, 340 \mathrm{~g}, 440 \mathrm{~g}$, dan $540 \mathrm{~g}^{\text {polybag }}{ }^{-1}$. Pemberian perlakuan rekomendasi pemupukan NPKMg $44 \mathrm{~g}^{\text {polybag-1 }}{ }^{-1}$ menghasilkan luas daun total terkecil yaitu $891,50 \mathrm{~cm}^{2}$.

Tabel 4. Rata-rata luas daun total bibit kelapa sawit umur 12 MST

\begin{tabular}{lc}
\hline Perlakuan & Luas Daun Total $\left.\mathbf{( c m}^{2}\right)$ \\
\hline Pemupukan NPKMg 44 g polybag $^{-1}$ & $891,50 \mathrm{~b}$ \\
Decanter solid 140 g polybag $^{-1}$ & $1375,18 \mathrm{a}$ \\
Decanter solid 240 g polybag $^{-1}$ & $1165,88 \mathrm{ab}$ \\
Decanter solid 340 g polybag $^{-1}$ & $1317,14 \mathrm{a}$ \\
Decanter solid 440 g polybag $^{-1}$ & $1182,00 \mathrm{ab}$ \\
Decanter solid 540 g polybag $^{-1}$ & $1187,18 \mathrm{ab}$ \\
\hline Keterangan : Angka-angka yang diikuti oleh huruf yang sama berbeda tidak nyata menurut uji DNMRT pada taraf \\
$\quad \alpha=5 \%$.
\end{tabular}

\section{Bobot Kering Tajuk}

Berdasarkan hasil analisis ragam menunjukkan bahwa perlakuan pemberian decanter solid dengan penambahan $13 \mathrm{~g}$ pupuk TSP tidak berpengaruh nyata terhadap bobot kering tajuk bibit kelapa sawit. Hasil uji Duncan pada taraf $a=5 \%$ terhadap bobot kering tajuk bibit dapat dilihat pada Tabel 5 .

Tabel 5. Rata-rata bobot kering tajuk bibit kelapa sawit umur 12 MST

\begin{tabular}{lc}
\hline Perlakuan & Bobot Kering Tajuk (g) \\
\hline Pemupukan NPKMg 44 g polybag-1 & $23,38 \mathrm{a}$ \\
Decanter solid 140 g polybag-1 & $43,63 \mathrm{a}$ \\
Decanter solid 240 g polybag & $34,38 \mathrm{a}$ \\
Decanter solid 340 g polybag & \\
Decanter solid 440 g polybag-1 & $40,13 \mathrm{a}$ \\
Decanter solid 540 g polybag & $34,38 \mathrm{a}$ \\
\hline
\end{tabular}

Keterangan :Angka-angka yang diikuti oleh huruf yang sama berbeda tidak nyata menurut uji DNMRT pada taraf $\alpha$ $=5 \%$.

Pada Tabel 5 menunjukan bahwa pemberian decanter solid dengan penambahan pupuk TSP memberikan perbedaan yang tidak nyata terhadap bobot kering tajuk. Pemberian perlakuan decanter solid $140 \mathrm{~g} \mathrm{polybag}^{-1}$ dengan penambahan $13 \mathrm{~g}$ pupuk TSP menghasilkan bobot kering tajuk yang terbesar yaitu 43,63 $\mathrm{g}$, sedangkan pemberian perlakuan NPKMg $44 \mathrm{~g}^{\text {polybag }}{ }^{-1}$ menghasilkan bobot kering tajuk terkecil yaitu 23,38 g.

\section{Bobot Kering Akar}

Berdasarkan hasil analisis ragam menunjukkan bahwa perlakuan pemberian decanter solid yang ditambah 13 g pupuk TSP tidak berpengaruh nyata terhadap bobot kering akar bibit kelapa sawit. Hasil uji Duncan pada taraf $a=$ $5 \%$ terhadap bobot kering akar bibit dapat dilihat pada Tabel 6 .

Berdasarkan Tabel 6 menunjukan bahwa pemberian perlakuan decanter solid $140 \mathrm{~g}_{\text {polybag }}{ }^{-1}$ menghasilkan bobot kering akar terbesar yaitu 13,00 g. Pemberian decanter solid $140 \mathrm{~g}$ ini berbeda nyata dengan pemberian perlakuan pupuk NPKMg $44 \mathrm{~g}$ polybag $^{-1}$, namun berbeda tidak nyata dengan pemberian pemberian decanter solid dengan dosis berturut-turut ; $240 \mathrm{~g}, 340 \mathrm{~g}, 440 \mathrm{~g}$, dan $540 \mathrm{~g}^{\text {polybag }}{ }^{-1}$, namun berbeda tidak nyata dengan pemberian pemberian decanter solid dengan dosis berturut-turut ; $240 \mathrm{~g}, 340 \mathrm{~g}, 440 \mathrm{~g}$, dan $540 \mathrm{~g}^{2}$ polybag $^{-1}$. Pemberian perlakuan NPKMg $44 \mathrm{~g}_{\text {polybag }}{ }^{-1}$ menghasilkan bobot kering akar terkecil yaitu $6,75 \mathrm{~g}$. 
Sarman Sarman, Elly Indraswari dan Ahmad Husni. Respons Pertumbuhan Bibit Kelapa Sawit (Elaeis guineensis Jacq.)

Tabel 6. Rata-rata bobot kering akar bibit kelapa sawit umur 12 MST

\begin{tabular}{lc}
\hline Perlakuan & Bobot Kering Akar $(\mathbf{g})$ \\
\hline Pemupukan NPKMg 44 g polybag $^{-1}$ & $6,75 \mathrm{~b}$ \\
Decanter solid $140 \mathrm{~g} \mathrm{polybag}^{-1}$ & $13,00 \mathrm{a}$ \\
Decanter solid 240 g polybag & $10,63 \mathrm{ab}$ \\
Decanter solid $340 \mathrm{~g} \mathrm{polybag}^{-1}$ & $10,50 \mathrm{ab}$ \\
Decanter solid 440 g polybag & $11,38 \mathrm{ab}$ \\
Decanter solid 540 g polybag & $11,00 \mathrm{ab}$ \\
\hline
\end{tabular}

Keterangan :Angka-angka yang diikuti oleh huruf yang sama berbeda tidak nyata menurut uji DNMRT pada taraf $\alpha=5 \%$.

\section{Rasio Tajuk Akar}

Berdasarkan hasil analisis ragam menunjukkan bahwa perlakuan pemberian decanter solid yang ditambahkan pupukTSP tidak berpengaruh nyata terhadap rasio tajuk akar bibit kelapa sawit. Hasil uji Duncan pada taraf $a=5 \%$ terhadap rasio tajuk akar bibit dapat dilihat pada Tabel 7 .

Tabel 7. Rata-rata rasio tajuk akar bibit kelapa sawit umur 12 MST

\section{Perlakuan}

\begin{tabular}{|c|c|}
\hline 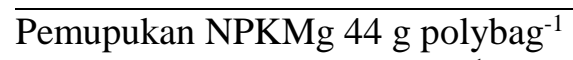 & $3,5 \mathrm{a}$ \\
\hline Decanter solid $140 \mathrm{~g}^{\text {polybag }}{ }^{-1}$ & 3,4 a \\
\hline Decanter solid $240 \mathrm{~g}$ polybag ${ }^{-1}$ & 3,2 a \\
\hline Decanter solid $340 \mathrm{~g}$ olybag ${ }^{-1}$ & 3,8 a \\
\hline Decanter solid $440 \mathrm{~g}$ polybag ${ }^{-1}$ & 3,0 a \\
\hline Decanter solid $540 \mathrm{~g}$ polybag $^{-1}$ & $3,4 \mathrm{a}$ \\
\hline
\end{tabular}

Pada Tabel 7 terlihat bahwa pemberian decanter solid yang ditambah $13 \mathrm{~g}$ pupuk TSP memberikan perbedaan tidak nyata terhadap rasio tajuk akar bibit kelapa sawit. Begitu juga halnya jika dibandingkan antara pemberian decanter solid dengan pemupukan NPKMg sesuai rekomendasi tidak berbeda nyata.

\section{PEMBAHASAN}

Hasil pengamatan pertumbuhan bibit kelapa sawit pada pertambahan tinggi bibit terlihat bahwa pemberian decanter solid sebanyak $140 \mathrm{~g}$ yang ditambah $13 \mathrm{~g}$ pupuk TSP merupakan perlakuan terbaik dan berpengaruh nyata terhadap pertambahan tinggi tanaman dan mampu melebihi pertambahan tinggi bibit rekomendasi pemupukan, hal ini dikarenakan kandungan nitrogen decanter yang merupakan unsur hara penting yang diperlukan untuk pertumbuhan vegetatif tanaman, hal ini sejalan dengan pendapat Mangoensoekarjo dan Semangun (2005 dalam Novsel, 2016) bahwa decanter solid mengandung nitrogen yang berfungsi sebagai penyusun utama biomassa tanaman muda yang berperan dalam merangsang pertumbuhan vegetatif yaitu menambah tinggi tanaman dan merangsang pertumbuhan daun. Kemudian didukung oleh pendapat Lingga dan Marsono (2008), bahwa penambahan unsur hara nitrogen dapat merangsang pertumbuhan vegetatif yaitu cabang, batang dan daun yang merupakan komponen penyusun asam amino, protein dan pembentuk protoplasma sel yang juga dapat berfungsi dalam merangsang pertumbuhan tinggi tanaman

Pengamatan pada variabel pertambahan jumlah daun menunjukan bahwa pemberian perlakuan kombinasi decanter solid dan TSP menghasilkan perbedaan tidak nyata dengan pertambahan jumlah daun yang diberi perlakuan pemupukan sesuai rekomendasi, adanya perbedaan tidak nyata terhadap pertambahan jumlah daun ini diduga disebabkan adanya pengaruh genotip tanaman, hal ini sesuai dengan pendapat Pangaribuan (2001) menyatakan bahwa laju pembentukan daun relatif konstan, jika tanaman ditumbuhkan pada kondisi suhu dan instensitas cahaya yang juga konstan, pada penelitian ini suhu rata- rata pada bulan pertama penelitian yaitu $27,33^{\circ} \mathrm{C}$ bulan kedua penelitian $26,33^{\circ} \mathrm{C}$ dan bulan ketiga penelitian $27^{\circ} \mathrm{C}$. Pertambahan jumlah daun ditentukan oleh sifat genetis tanaman dan lingkungan, yaitu pada bibit kelapa sawit dihasilkan 1-2 helai daun setiap bulannya sehingga pertambahan jumlah daun pada bibit kelapa sawit berlangsung relatif sama setiap bulannya (Hidayat, 1994). Pemberian perlakuan pupuk decanter solid $140 \mathrm{~g}$ polybag $^{-1}$ dengan penambahan $13 \mathrm{~g}$ pupuk TSP menunjukan pertambahan jumlah daun tertinggi, hal ini diduga karena kandungan nitrogen pada decanter solid yang diserap tanaman dapat merangsang pembentukan daun baru, sejalan dengan pendapat Lakitan (2004), unsur hara yang paling berpengaruh terhadap 
pertumbuhan dan perkembangan daun adalah nitrogen. Lingga dan Marsono (2008) menyatakan bahwa peran utama $\mathrm{N}$ adalah mempercepat pertumbuhan secara keseluruhan terutama batang dan daun. Selain dari unsur $\mathrm{N}$ yang dikandung oleh decanter solid, unsur P yang terdapat pada decanter solid dan pupuk TSP juga berpengaruh terhadap pertumbuhan daun bibit kelapa sawit, seperti pendapat Nurjaya et al. (2009), menyatakan P berperan sangat penting pada pertumbuhan bibit kelapa sawit terutama dalam pertumbuhan daun tanaman. Kekurangan unsur $\mathrm{P}$ akan menyebabkan pelepah daun memendek dan kerdil sehingga akan menghambat pertumbuhan tanaman.

Pengamatan pada variabel pertambahan diameter batang menunjukan bahwa kombinasi decanter solid dan TSP memberikan perbedaan tidak nyata terhadp pertambahan diameter batang yang diberi perlakuan pemupukan sesuai rekomendasi, hal ini diduga karena tanaman sawit merupakan tanaman tahunan, dimana respons pertumbuhan diameter bonggol terjadi lebih lambat dan membutuhkan waktu cukup lama dalam meningkatkan diameter bonggol. Hal ini dapat dilihat pada grafik pertambahan diameter bonggolb(Gambar 2), setiap bulannya diameter bonggol bertambah 2-5 mm. Menurut Rosman et al, (2004 dalam Juliana, 2018), hasil fotosintesis lebih banyak digunakan untuk pertumbuhan vertikal, seperti pertumbuhan tunas baru dari pada memperbesar batang, karena pertumbuhan aktif suatu tanaman lebih banyak pada pertumbuhan vertikal seperti di bagian pucuknya. Pertambahan diameter batang menghasilkan diameter yang terbesar terdapat pada perlakuan pemberian decanter solid 440 gr polybag $^{-1}$ dengan penambahan 13 gr TSP yaitu $15,30 \mathrm{~mm}$, hal ini dikarenakan unsur hara $\mathrm{K}$ yang terkandung dalam decanter solid dapat mempengaruhi pembesaran diameter batang, hal ini sejalan dengan pendapat Siregar et al., (2015) menyatakan bahwa pembesaran bonggol bibit kelapa sawit dipengaruhi oleh tersedianya unsur hara nitrogen, fosfor, dan kalium bagi tanaman, namun yang sangat berperan yaitu unsur hara $\mathrm{K}$. Tersedianya unsur hara $\mathrm{K}$ maka pembentukan karbohidrat akan berjalan dengan baik dan translokasi pati ke bonggol bibit akan semakin lancar, sehingga akan terbentuk bonggol bibit yang baik. Kemudian dikemukakan oleh Lingga dan Marsono (2008) bahwa unsur K berfungsi menguatkan batang tanaman yang dapat mempengaruhi besar diameter batang.

Pemberian decanter solid dan TSP dapat menigkatkan parameter luas daun total bibit tanaman kelapa sawit. Pada hasil pengamatan pertumbuhan bibit tanaman kelapa sawit pada parameter luas daun total tanaman dengan pemberian kombinasi decanter solid $140 \mathrm{~g}$ polybag $^{-1}$ dengan penambahan $13 \mathrm{~g}$ pupuk TSP merupakan perlakuan terbaik dan bebeda nyata dengan perlakuan NPKMg $44 \mathrm{~g}$ polybag $^{-1}$ dengan rata - rata luas daun total yang paling tinggi yaitu $1.375,18 \mathrm{~cm}^{2}$. Hal ini diduga kandungan unsur hara yang terdapat dalam decanter solid dapat memperbaki struktur tanah, yang mampu mendukung pertumbuhan luas daun total bibit kelapa sawit, sejalan dengan pendapat Vitta (2012 dalam Maryani, 2018), bahwa unsur hara yang tersedia dalam media bibit yang telah diberi decenter solid dapat memperbaiki struktur tanah sehingga pertumbuhan akar menjadi baik, penyerapan air oleh tanaman menjadi meningkat, sehingga mampu mendukung pertumbuhan tanaman dan peningkatan luas daun

Pengamatan pada variabel bobot kering tajuk menunjukan bahwa pemberian decanter solid $140 \mathrm{~g} \mathrm{polybag}^{-1}$ dengan penambahan 13 gr pupuk TSP memperlihatkan bobot kering tajuk tertinggi dibandingkan pemberian perlakuan lainnya yaitu 43,63 g, adanya perbedaan tidak nyata pada bobot kering tajuk bibit kelapa sawit berhubungan dengan pertambahan jumlah daun dan pertambahan diameter batang bibit kelapa sawit, kedua parameter ini juga berbeda tidak nyata. Berat kering tajuk berhubungan dengan parameter pertambahan tinggi tanaman, pertambahan jumlah daun, dan diameter batang karena berat kering tajuk merupakan akumulasi dari organorgan tanaman sehingga semakin tinggi bibit, semakin banyak jumlah daun, semakin besar diameter batang maka bobot kering tajuk juga akan lebih besar. Berat kering tajuk berkaitan dengan pemanfaatan unsur hara $\mathrm{N}, \mathrm{P}$ dan $\mathrm{K}$ yang optimal dari decanter solid dan pupuk TSP dapat meningkatkan klorofil yang akan mempengaruhi proses fotosintesis dalam menghasilkan asimilat dan mempengaruhi berat kering tajuk bibit kelapa sawit, seperti pendapat Pahan (2010) bahwa meningkatnya klorofil, maka akan meningkat aktivitas fotosintesis dalam menghasilkan asimilat yang mempengaruhi berat kering tajuk tanaman. Kemudian menurut Lakitan (2004), bahwa meningkatnya sejumlah unsur hara yang dapat diserap tanaman secara tidak langsung akan meningkatkan proses fotosintesis yang akan menghasilkan fotosintat. Selanjutnya fotosintat yang dihasilkan disimpan dalam jaringan batang dan daun, hasil fotosintat tersebut yang kemudian dapat meningkatkan berat kering tanaman yang mencerminkan status nutrisi tanaman atau kemampuan tanaman untuk menyerap unsur hara. Jika serapan hara meningkat maka metabolisme tanaman akan semakin baik. Semakin baik proses metabolisme maka akan mempengaruhi berat kering tanaman (Fikri, 2013).

Pengamatan pada variabel bobot kering akar menunjukan bahwa pemberian decanter solid $140 \mathrm{~g} \mathrm{polybag}^{-1}$ dengan penambahan $13 \mathrm{~g}$ pupuk TSP menghasilkan bobot kering akar yang paling tinggi yaitu 13,00 g. Pemberian kombinasi decanter solid dan pupuk TSP mempengaruh sifat fisik tanah yaitu tanah akan menjadi gembur sehingga aerasi menjadi lebih baik serta mudah ditembus perakararan tanaman. Selanjutnya dijelaskan bahwa penggunaan pupuk organik dapat membuat tanah menjadi gembur sebab tanah yang gembur dapat meningkatkan perkembangan dan pertumbuhan akar, disamping itu tanah gembur juga mudah mengikat air, memiliki peredaran udara (aerasi) dan pembuangan air (drainase) yang baik sehingga di dalam tanah tersedia oksigen yang berguna bagi respirasi akar 
tanaman sehingga berpengaruh pada pemanjangan akar, namun disamping itu juga pemberian pupuk fosfat juga merangsang pertumbuhan akar, terutama akar lateral dan akar rambut (Sarief, 1986).

Pada pengamatan rasio tajuk akar perlakuan pemberian decanter solid pada berbagai dosis yang ditambah 13 g TSP memberikan efek yang sama terhadap nilai rasio tajuk akar. Nilai rasio tajuk akar ini juga tidak berbeda dengan dengan perlakuan rekomendasi pupuk NPKMg $44 \mathrm{~g}^{\text {polybag }}{ }^{-1}$. Hal ini menunjukkan bahwa pemberian decanter solid disamping memperbaik struktur media juga memberikan kontribusi terhadap hara media walaupun tidak begitu besar. Sejalan dengan hal ini, Haryadi et al (2015) menjelaskan bahwa nilai rasio tajuk akar menunjukkan pertumbuhan ideal tanaman. Hal ini diduga bahwa hasil fotosintesis banyak ditranslokasikan ke bagian tajuk dari pada ke akar tanaman, rasio tajuk akar merupakan faktor penting dalam pertumbuhan tanaman dimana mencerminkan proses penyerapan unsur hara. Terpenuhinya kebutuhan hara dan ketersediaan air bagi tanaman sangat menentukan peningkatan rasio tajuk akar

\section{KESIMPULAN}

Berdasarkan hasil penelitian disimpulkan bahwa pemberian decanter solid pada berbagai dosis dengan penambahan pupuk TSP mampu meningkatkan pertambahan beberapa bagian vegetatif bibit kelapa sawit walaupun belum terhadap semua variabel yang diamati. Pemberian decanter solid mampu menyamai pertumbuhan bibit pada perlakuan dosis rekomendasi pemupukan untuk bibit kelapa sawit. Pemberian decanter solid $140 \mathrm{~g} \mathrm{polybag}^{-1}$ dengan penambahan $13 \mathrm{~g}$ TSP dapat direkomendasikan untuk dimanfaatkan sebagai bahan campuran media pembibitan bibit kelapa sawit di pembibitan utama.

\section{DAPTAR PUSTAKA}

Fikri, K. 2013. Pengaruh volume media dalam polybag terhadap pertumbuhan bibit kelapa sawit.Skripsi Fakultas Pertanian Universitas Riau.Pekanbaru. 1 (1) 1-8

Haryadi D., H. Yetti., dan S. Yoseva. 2015. Pengaruh Pemberian Beberapa Jenis Pupuk Terhadap Pertumbuhan Dan Produksi Tanaman Kailan (Brassica alboglabra L.). Jom Faperta 2 (2)

Hertos, M. 2013. Pengaruh Pemberian Pupuk Kandang Ayam Dan Pupuk NPK Mutiara Terhadap Pertumbuhan Bibit Kelapa Sawit (Elaeis guineensis Jacq) Pada Pertumbuhan Pembibitan Pre Nursery. Jurnal Anterior. 13(01); $1-9$.

Juliana, 2018. Respon Pertumbuhan Bibit Kelapa Sawit (Elaeis Guineensis Jacq) Dengan Pemberian Campuran Pupuk Kandang Kambing Dan Arang Sekam Pada Tanah Bekas Tambang Batu Bara. Skripsi Fakultas pertanian Universitas Jambi

Lakitan, B. 2004. Dasar Dasar Fisiologi Tumbuhan. Jakarta. PT. Raja Grafindo Perkasa.205 Hal.

Lingga, P dan Marsono. 2008. Petunjuk Penggunaan Pupuk. Penebar Swadaya. Jakarta.156 Hal.

Maryani, A.T. 2018.Efek Pemberian Decanter Solid Terhadap Pertumbuhan Bibit Kelapa Sawit (Elaeis Guineensis Jacq) Dengan Media Tanah Bekas Lahan Tambang Batu Bara Di Pembibitan Utama.Caraka Tani: Journal Of Sustainable Agriculture. 33(1), 50-56.

Novsel A, 2016. Pengaruh.Pemberian (Decanter Solid) Sebagai Subsitusi Pupuk NPK (15:15:6:4) Terhadap Pertumbuhan Bibit Kelapa Sawit Di Pembibitan Utama.Skripsi Fakultas Pertanian Universitas Jambi.

Nurjaya, A. Kasno, dan A. Rachman. 2009. Penggunaan Fosfat Alam Untuk Tanaman Perkebunan. Badan Penelitian dan Pengembangan Pertanian, Departemen Pertanian. Bogor. Dalam Hidayat Agus T Saleh B, Hermansyah (2017). Pengaruh Pupuk organik limbah kelapa sawit dan pupuk organik terhadap pertumbuhan bibit kelapa sawit pada pembibitan utama. Akta Agrosia, 20 (1):1-8.

Pahan, I. 2010. Panduan Lengkap Kelapa Sawit Manajemen Agribisnis Dari Hulu Hingga Hilir. Jakarta : Penebar Swadaya, $412 \mathrm{Hal}$.

Pangaribuan Y. 2001 "Studi Karakter Morfologi Tanaman Kelapa Sawit Di Pembibitan Terhadap Cekaman Kekeringan".Tesis.Institut Pertanian Bogor.

Siregar LT, Wardati, dan Armaini. 2015. Pemberian Limbah Cair Biogas Sebagai Pupuk Organik Pada Tanaman Kelapa Sawit (Elaeis guineensis Jacq.) Di Pembibitan Utama. Jom Faperta 2 (1).

Sarief E.S 1986. Kesuburan Dan Pemupukan Tanah Pertanian. Pustaka Buana. Bandung. 